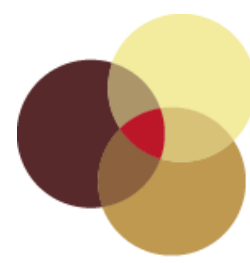

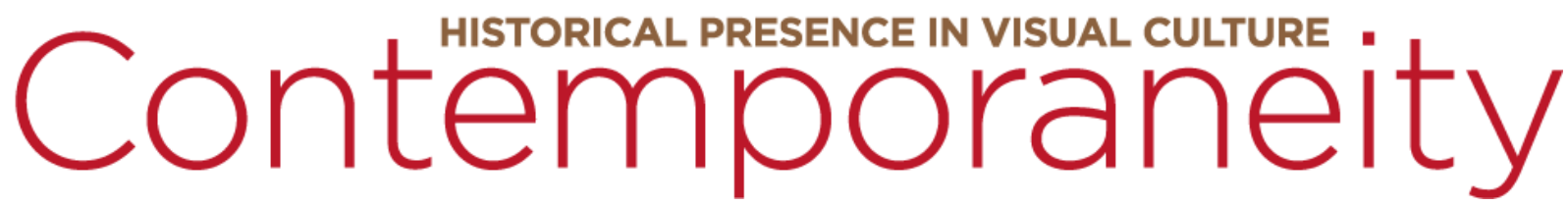

Vol 5, No 1 "Agency in Motion" (2016) | ISSN 2155-1162 (online) | DOI

$10.5195 /$ contemp.2016.170

http://contemporaneity.pitt.edu

\title{
James Luna and the Paradoxically Present Vanishing Indian
}

Elizabeth S. Hawley

\begin{abstract}
James Luna's performances interrogate how representations of Native Americans have been made to fit western assumptions about the "real Indian." Using his recognizably Native body as a marker of both presence and endangered existence, Luna links Peggy Phelan's conception of performance as the presence of loss with the centuries-old stereotype of Native Americans as the "vanishing race"-a stereotype that continues to exert influence. In Take a Picture with a Real Indian (performed in 1992, 2001, and 2010), he invites viewers to have their photograph taken with him wearing one of three options: war dance regalia, a loincloth, or khakis and a polo shirt. Few people choose the third option. The performance foregrounds what has become a tradition of Native Americans performing/posing their native -ness as Otherness for the camera, strategically employing imagery that plays to nostalgic Western views of Native peoples as perpetually vanishing. I argue that Luna's performances comment not only upon western preconceptions of Native Americans, but also upon the ways that Native Americans have historically reasserted their agency by manipulating such expectations, staging themselves to fit the stereotype.
\end{abstract}

\section{About the Author}

Elizabeth S. Hawley is a PhD Candidate in Art History at the CUNY Graduate Center. Her dissertation analyzes the art production in Santa Fe, New Mexico in the early twentieth century, putting the works of American Modernists who visited the area into dialogue with the works of Native artists from the surrounding Pueblos. Hawley earned her MA from the Courtauld Institute of Art, and her BA from Harvard University. She recently completed a Museum Research Consortium Fellowship at the Museum of Modern Art, New York, where she undertook research on Frank Lloyd Wright's use of Native and Meso-American forms in his architecture and decorative designs. She is currently teaching art history courses at York College and St. Francis College. 


\section{James Luna and the Paradoxically Present Vanishing Indian}

\section{Take a Picture}

On October 12, 1911-Columbus Day-Ho-Chunk artist Angel DeCora took to the podium at a Society of American Indians conference to give a talk on Native American art. She argued for the development of the "decorative instinct of the Indian to modern methods" in response to the rapid and continual renegotiation of her people's position in society and history. ${ }^{1}$ DeCora concluded her rousing speech with the assertion that "the Indian in his native dress is a thing of the past, but his art that is inborn shall endure."2

Nearly a century later contemporary Luiseño performance artist James Luna used the occasion of Columbus Day to stage a work that indeed proved DeCora's prediction of the endurance of what she termed "Indian art" prescient, albeit in a postmodern, parody-laced manner that continued to incorporate the native dress DeCora already assumed anachronistic. In the performance, provocatively titled Take a Picture with a Real Indian (2010), Luna placed three life-size, black and white cardboard cutouts of himself at the base of the Columbus Memorial, a park-like traffic circle adjacent to the capital grounds in Washington, D.C. that houses a huge statue of the man who claimed to have discovered America (fig. 1). The memorial immediately calls forth stereotypes of the Indian against which Luna positions his own work: on the west side of the sculpture, an unnamed American Indian kneels at Columbus's feet, and an inscription claiming that Columbus "gave to mankind a New World" leaves unacknowledged the fact that American Indians had inhabited this land for centuries, and further denies them a place in the Euro-American conceptualization of "mankind."

Against this backdrop Luna positioned three cutouts of himself clad in different clothing: in one he wears a buckskin breechcloth and moccasins; in the next, he sports regalia including feathered headwear and a beaded breastplate; and in the third, he appears dressed in khakis and a polo shirt. Luna then stepped onto the makeshift stage that had been placed between the cutouts three times, each time wearing a version of the costumes depicted in the cutouts, and each time reciting, "Take a picture with a real Indian. Take a picture on this beautiful sunny day. Take a picture with a real Indian on one of the saddest days of our history . . . America needs to face up to reality. America needs to put down the romanticism. " ${ }^{3}$ He explained to audience members that they could only have their picture taken with him once by one of the professional photographers he hired for the occasion. The photographers would produce two Polaroids, one to be left with the artist, and one for the audience member to keep as a memento. Viewers then approached the stage to have their

\footnotetext{
${ }^{1}$ A ngel DeCora, "Native Indian A rt," in Report of the Executive on the Proceedings of the First Annual Conference of the Society of American Indians Held at the University of Ohio, Columbus, O hio (O ctober 12 -17,1911), 1:84. For further information on DeC ora see Elizabeth Hutchinson, The Indian Craze: Primitivism, Modernis m, and Transculturation in American Art, 1890-1915 (Durham: Duke University Press, 2009).

2 DeCora, "N ative Indian Art," 87.

${ }^{3}$ James Luna, Take a Picture with a Real Indian performed in 2010, Was hington D.C. National Museum of the A meric an Indian performance recording, accessed from http://www.facebook.com/video/video.php?v=10100243886416480.
} 
photo taken with whichever clothing-designated iteration of the artist that they felt best represented a "real Indian." ${ }^{4}$ Perhaps inevitably, most participants chose to be photographed with Luna while he was wearing his regalia.

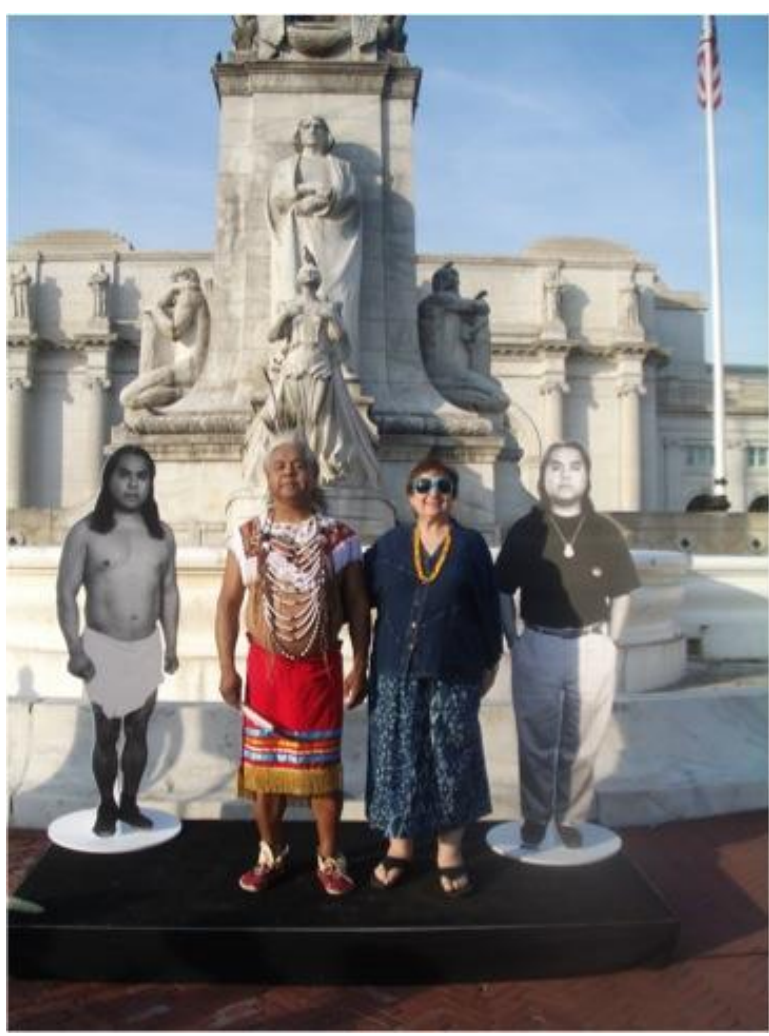

\section{Figure 1}

James Luna, Take a Picture with a Real Indian, 2010 . Live performanceinstallation with photographs, Washington, D.C.P hotographer unknown. I mage courtesy of James Luna.

Take a Picture is particularly pointed in its interrogation of the pose and the photograph, and how both Native and non-Native peoples are implicated in and affected by the resulting stereotypes: Native peoples are expected to adhere to the stereotypic construction of Indian identity, but in performing this role, they reify the stereotype. At the same time, non-Native peoples perpetuate the problematic cycle by only characterizing as "Indian" those Native peoples that adhere to the stereotype that non-Native peoples have constructed and come to expect. This article addresses the ways in which Luna's performance engages with the history of such constructions, their problematic persistence in the present, and the evolution of theoretical discourse around these issues.

Luna often restages his works, and the 2010 performance of Take a Picture was itse If a reenactment. The cardboard cutouts of Luna depict him as a younger man and can be seen in a photograph of his original performance of the piece at the Whitney Museum of Art in 1991 (fig. 2). As Amelia Jones observes, "re-enactments remind us all that present

\footnotetext{
${ }^{4}$ When I use the term "real Indian" in the following article, I a m alluding to Luna's conception of an Indian identity that fits -or is constructed to fit-non-Native expectations.
} 
experience, including . . . the apprehension of things called 'art' or acts called 'performance,' is only ever available through subjective perception." ${ }^{5}$ Luna's performance at the base of the Columbus monument doubled such subjectivity: he staged a long-standing stereotype of the Native American and did so within the context of a performance that has had previous iterations. Nearly twenty years after the first performance, he tested whether the outcome of the 2010 version would be less starkly stereotypical in terms of audience subjectivity. He perhaps expected participants to be less inclined to deem his regalia-clad self the real Indian, since such categorization is a fallacy, and none of the three characters performed by Luna can be declared more "Indian" than the others. The performance, however, played out much as it had two decades before, which he had described thus:

It . . . was leading-There was an Indian in a breechcloth with everybody going 'Oh wow, there's an Indian.' Then I came out in my street clothes and they said, 'Oh, there's a guy.' But when I came out in my regalia, I knew that it would get that response from the audience. Everybody went for it. There was a big ooh and aah when I stepped up on that pedestal with my war dance outfit. They forgot about all the rest and really lined up to have their picture taken. This is the memento that they really wanted. Even people that were art savvy fell for it. 6

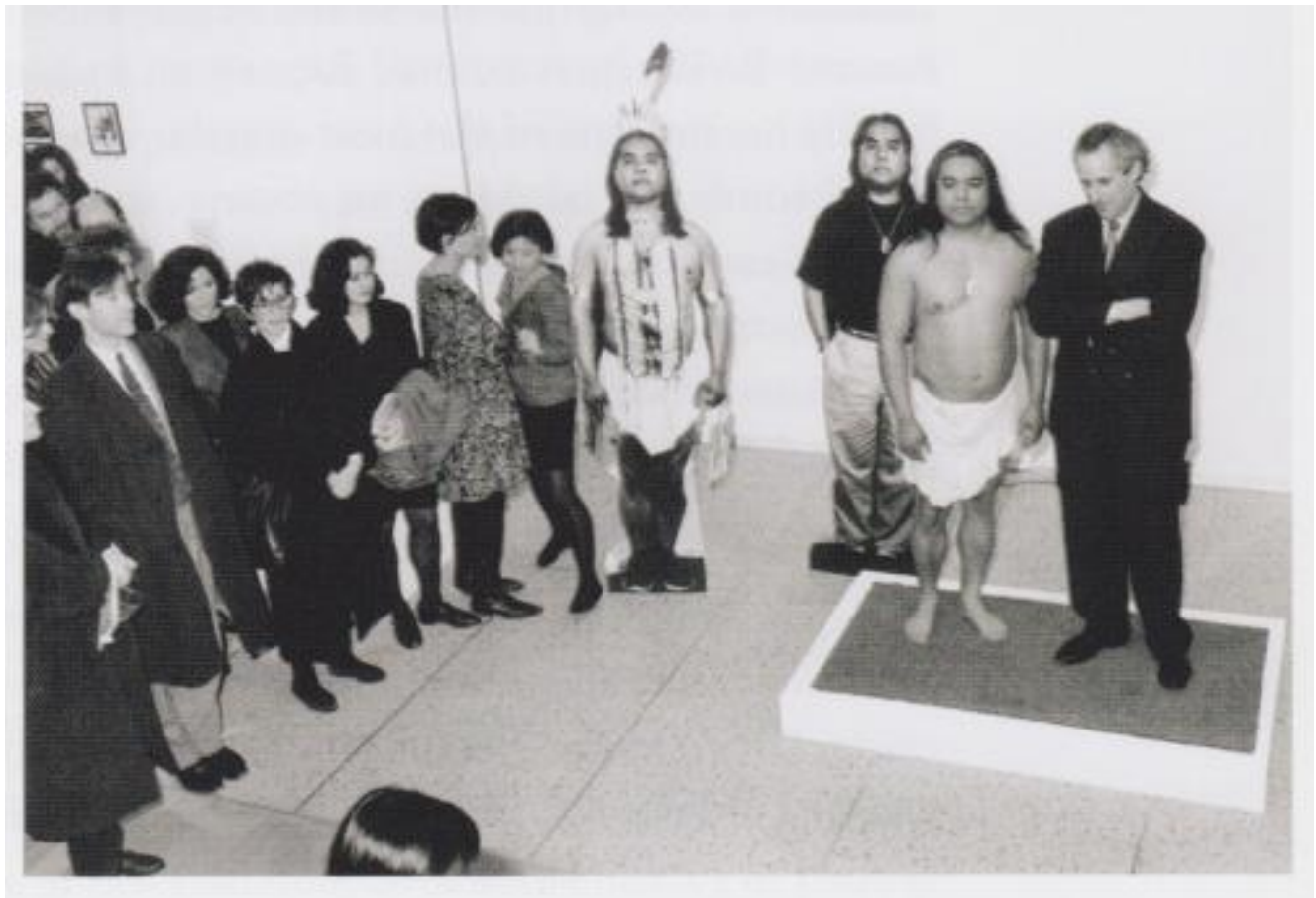

Figure 2

James Luna, Take a Picture with a Real Indian, 1991. Live performance-installation with photographs, Whitney Mus eum of A merican A rt. P hotographer unknown. I mage courtesy of James Luna.

\footnotetext{
${ }^{5}$ A melia Jones, "'The A rtist is Present': A rtistic Re-enactments and the Impossibility of Presence," TDR: The Drama Review 55, no. 1 (Spring 2011): 42.

${ }^{6}$ Kenneth R. Fletcher, "James Luna," Smithsonian Magazine (A pril 2008 ), http://www.s mithsonianmag.com/arts-culture/james-luna-30545878/.
} 
Of course, having his audience members "fall for" this outcome was crucial to the message of the work; in order to point to the persistence of Native stereotypes, Luna had to create a situation in which they are unlikely to be overcome. His use of the term "leading" is telling, for the manner in which the work was presented ensured a certain scripted outcome, and failure to achieve this outcome would have detracted from the artist's intended message by rendering it an overstatement. The cutouts informed viewers which costumes Lu na would don during the performance and by saving the best for last, so to speak, he set up a situation in which the majority of photographs would be taken of his last appearance, both because this costume is the most visually striking and because it was the last chance to take a photograph-the grand finale of the performance. Agency, here, was with the artist; Luna was in control, manipulating audience members to achieve a more powerful statement with the work. But in doing so, he re-inscribed the stereotypes of Indian identity against which the work was ostensibly aimed. Then again, while the "art savvy" people may have been duped, they also may have been consciously participating in Luna's performance of paro dic, scripted stereotypes. Perhaps aware of Luna's intended message, it is possible that these viewers played the role of uninformed audience members ignorant of contemporary Native American experiences and concerns, as expected-needed even-by the artist.

Luna mentions these savvy spectators because, as with most of his works, he first performed Take a Picture in a museum. Staging the work outside of the museum context in 2010 marked an intriguing departure from his usual practice and caused a change in the scripted quality of the piece. It gave viewers both more and less command over their own actions: more in that Luna could not control unauthorized photographs of a performance staged in a public space, and less in that some viewers stumbled upon the work, thus receiving only a fragmentary explanation of it and what their actions might signify. ${ }^{7}$ And while the towering Columbus monument provided a politically suggestive backdrop to the performance that took place on a controversial national holiday, I argue that as a public space it also foregrounded the significance of photography in the work. ${ }^{8}$

Luna's earlier performances of the piece include the aforementioned 1991 Whitney Museum location, as well as a 2001 staging at the Herbert F. Johnson Museum of Art at Cornell University. ${ }^{9}$ In these contexts, the "take a picture, leave a picture" component of the performance could be better enforced, since museum photography policies and the guards who enforce them would have discouraged participants from taking their own photographs. Indeed, the institutional setting protected Luna and his performance from concerns varying from copyright infringement to potential heckling. In the open space of the monument, however, Luna's posed body became subject to unauthorized photographs taken by any one in the area. Holly Stewart, Social Media Coordinator of the National Museum of the American Indian, noted that "the setting was inspired," and described "a second ring of audience-

\footnotetext{
7 The performance was sponsored by the Smithsonian's N ational Museum of the A merican Indian in as sociation with "V antage Point: The Contemporary Native A merican A rt Collection," an exhibition that highlighted the work of twenty-five contemporary Native A merican artists working in all media, including performance.

8 That morning, the U.S. Marines had held their a nnual ceremony in honor of Columbus Day and had placed wreaths of flowers on the other side of the statue. This evidence of their nationalistic reverence stood in stark contrast to Luna's subsequent performance on the opposite side of both the statue and the ideology to which it bears witness.

${ }^{9}$ A curtailed version of the work was also staged in Times Square, New York City in 1994 as part of The $42^{\text {nd }}$ Street Art Project. In this piece, the three cutouts were placed in a small storefront window and an audio element instructed passersby as to the intent of the work.
} 
participants snapping photographs from taxis and tour buses." ${ }^{10}$ The photographs resulting from this outer edge of action were a consequence of the public setting as well as contemporary image culture itself, in which nearly anyone with a phone has the capability of quickly documenting moments, memorable or not, from their day-to-day experiences. Such was not the case at the original staging of Take a Picture, both because the museum context set a tone of respectful audience obedience in terms of documentation, and simply because cameras were less common and more obtrusive. Attempting to regulate images of their work has become increasingly difficult for performance artists, particularly for pieces performed in public. The 2010 version of Take a Picture created a mise-en-abyme of photos-carefully composed by Luna's professional photographers, amusedly taken by friends of the participants who ventured onstage, and hastily snapped by confused but intrigued passengers in cars swinging around the traffic circle. Luna's performance here thus alluded to both our contemporary conceptualization of photography and documentation, as well as to Luna's loss of control concerning the image of himself and his art.

\section{Reading Photographs of Native Americans}

The latter aspect speaks to a long history of non-Native photographers turning Native Americans into the unknowing, hesitant, or unwilling subjects of their images. Scholars in the 1980s and 1990s frequently referenced these histories in their analyses of photographs depicting Native peoples, often comparing the photographer's camera to the colonizer's gun: Vine Deloria, Jr. calls early twentieth-century photography "a weapon in the final skirmishes of cultural warfare in which the natives of North America could be properly and finally embedded in their places in the cultural evolutionary incline. ${ }^{11}$ Comanche curator Paul Chaat Smith takes this analogy a step further, arguing that just as the Walker Colt revolver was "a machine designed for one purpose: to kill Comanches ... There should have been a special camera invented to shoot Indians as well, given the tremendous influence photography has had on us." 12 Smith observes, "those [Indian coffee-table] books and the photographers behind them are like big game hunters on safari and their big game is the real Indian."13 The hunters ignore the "fourteen year old boy in baggy pants" and the "fat guy with the Marine haircut," just as Take a Picture participants seldom desired a picture with Luna in his khakis. ${ }^{14}$ The so-called real Indian sought by the camera-wielding hunters described by Smith was, and continues to be, the regalia-clad version of the real Indian in Luna's performance-the spectacle of Otherness.

Many Native Americans balked at the intrusive cameras, for a variety of reasons, but their desires to remain un-photographed were ignored. Some feared the implications of having their image replicated on paper; Lucy Lippard observes that the "transfer of a black and-white likeness to paper meant to some that a part of their lives had been taken away, to

\footnotetext{
${ }^{10}$ Holly Stewart, "James Luna: Take a Picture with a Real Indian," The National Museum of the American Indian Blog, O ctober 12, 2010 , http://blog.nmai.si.edu/main/2010/10/james-luna-take-a-picture-with-areal-indian.html.

${ }^{11}$ V ine Deloria, Jr., I ntroduction to Christopher M. Lyman, The Vanishing Race and Other I/lusions: Photographs of Indians by Edward S. Curtis (New York: Pantheon Books, 1982), 11.

12 Paul Chat Smith, "Ghost in the Machine" in Strong Hearts: Native American Visions and Voices, ed. Peggy Rolf (New York: A perture, 1995), $6-7$.

13 Ibid., 7 .

14 Ibid.
} 
others that their vital power had been diminished."15 However, this fear should not be overstated; the stereotype that Native Americans feared cameras would "steal their souls" has become an enduring and inaccurate perception. Other Native Americans objected to this exploitative photography not out of fear, but in protest against its intrusiveness. Jane Alison analyzes the literalized rhetoric of non-Natives taking photographs of Natives, emphasizing that these images are taken, not requested. ${ }^{16}$ James $C$. Faris examines unequal photographic encounters at length, pointing to images like Navajo Children (ca. 1925), which shows a missionary student and two young boys tightly grouped together as though to avoid the photographers that close in on them (fig. 3). The younger boy hides in the skirts of the student, as she and the older boy look away from both the photographer in the image, as well as the unknown photographer from whose view we access the scene. Just as the student and children avoid the immediate threat of the camera-wielding photographers, so too do they avoid the gaze of contemporary viewers, thus implicating the viewer in the invasive scene. Their evasion is echoed in Three Navajo girls wearing blankets (ca. 1936-1941), which shows three young Native American women, two with their heads turned and a third who casts her eyes downwards, refusing the gaze of the camera (fig. 4). Faris notes that this refusal is seen over and over again in photographic archives, and that "such photographs are often labeled 'shy women'-that is, in terms that do not condemn the photographer." 17

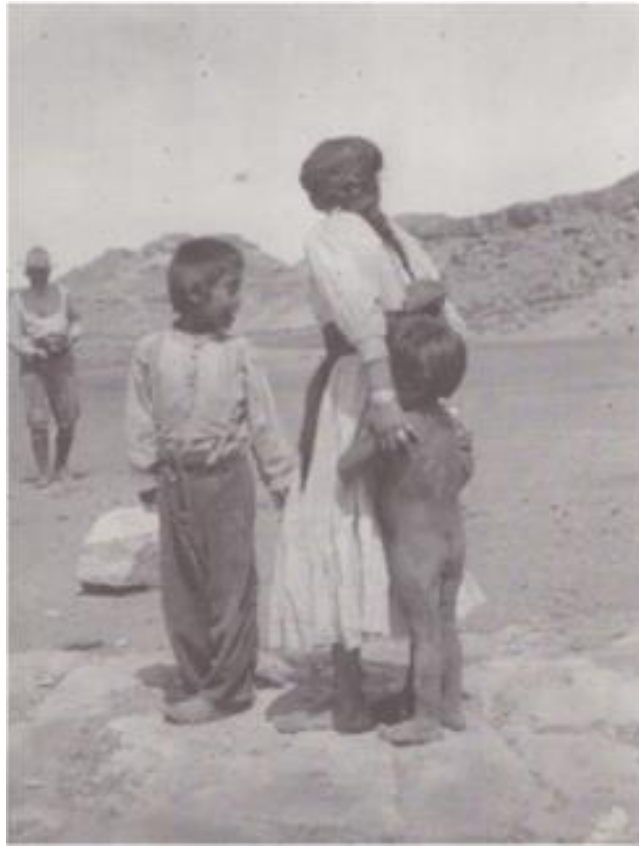

\section{Figure 3}

Photographer unknown, Navajo Children, ca. 1925 . I mage courtesy Palace of the Governors. Photo A rchives (NMHM/DCA), \#53801.

\footnotetext{
${ }^{15}$ Lucy R. Lippard, Introduction to Partial Recall: Photographs of Native North Americans (New York: The New Press, 1992), 30 -31.

${ }^{16}$ Jane A lison, Introduction to Native Nations: Journeys in American Photography (London: Barbican A rt Gallery, 1998), 14 .

17 James C. Faris, Navajo and Photography: A Critical History of the Representation of an American People (A lbuquerque: University of N ew Mexico Press, 1996), 47. Lucy Lippard also comments on this visual phenomenon, noting that, "[i]n the archives, there are many photographs of Native people hiding their faces or otherwise trying to avoid the camera... Soon it was recognized as the ultimate invasion of social religious, and individual privacy." Lippard, Partial Recall, 29.
} 


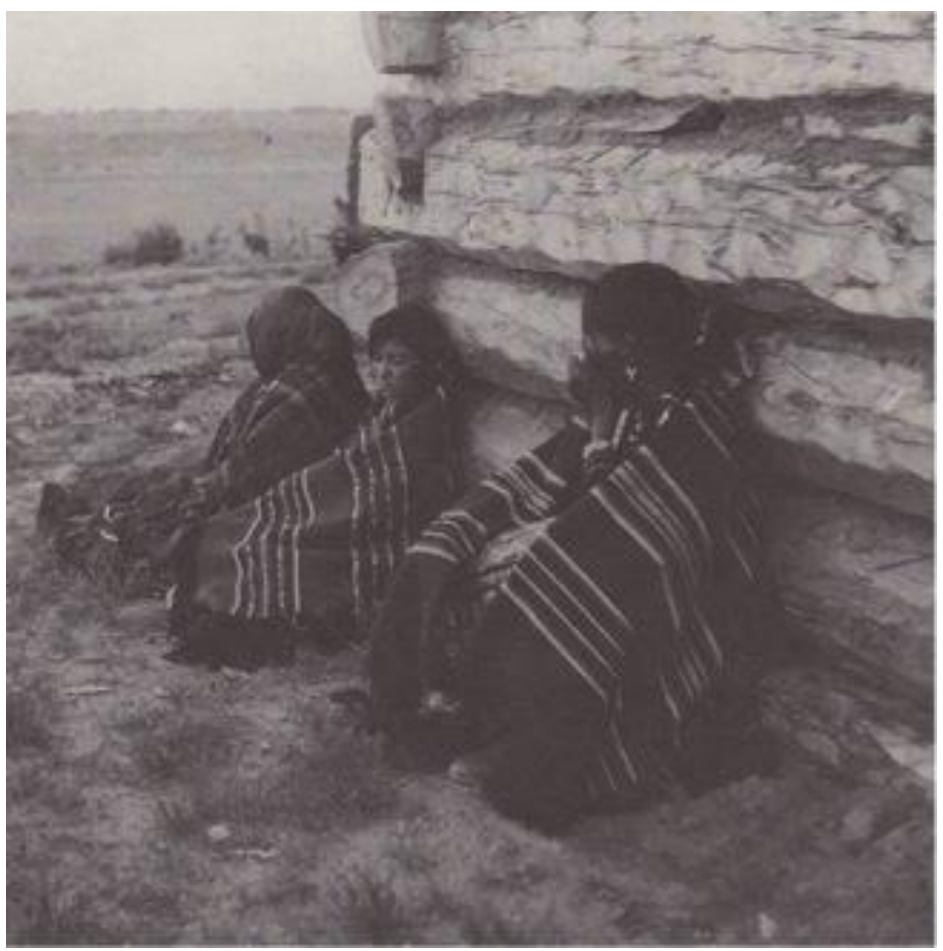

\section{Figure 4}

Helen M. Post, Three Navajo girls wearing blankets, ca. 1936-1941). Gelatin silver print, $8 \times 715 / 16$ in. Image courtes $y$ of the A mon Carter Museum, Fort Worth, TX, P1985.50.837.

Of course, not all Native Americans objected to cameras, and scholars should refrain from assuming that any image of a Native person is a portrayal of victimhood. If some Native Americans shunned cameras and photography, others were curious and used them to their advantage. Scholars in the last fifteen years have moved beyond analyzing the presumed objectification of Native subjects to instead examine Native cognizance, collaboration, and participation in the photographic process. Frank H. Goodyear argues that Lakota leader Red Cloud exploited photography and the Western fascination with his image to emphasize his continued existence and relevance in contemporary society. ${ }^{18}$ In his study of $\mathrm{H}$. H. Bennett's photographs of members of the Ho-Chunk nation, Steven D. Hoelscher argues that while photography has "served as a technology of domination to subdue indigenous peoples . . . it has also worked to provide those very peoples a medium for their cultural survival, endurance, and renewal-for their survivance. ${ }^{\prime 19}$

This concept of survivance, along with the related theories of contact zones and visual sovereignty has shifted the framework of analysis for such imagery. Gerald Vizenor defines survivance as "an active sense of presence, the continuance of native stories, not a mere reaction, or a survivable name," arguing that "Native survivance stories are renunciations of

\footnotetext{
${ }^{18}$ Frank H. Goodyear, Red Cloud: Photographs of a Lakota Chief (Lincoln: University of Nebraska Press, $2003)$.

${ }^{19}$ Steven D. Hoelscher, Picturing Indians: Photographic Encounters and Tourist Fantasies in H. H. Bennett's Wiscons in Dells (Madison: The University of Wisconsin P ress, 2008), 10.
} 
dominance, tragedy, and victimry."20 Native peoples do not just survive, they actively recalibrate cultural mores in ways that honor the past, accept the present, and anticipate the future. This takes place within social spaces that Mary Louise Pratt has termed contact zones. She acknowledges the imbalanced power relations, coercion, and conflict associated with such zones, but also notes, "while a subjugated people cannot readily control what emanates from the dominant culture, they do determine to varying extents what they use for their own, and what they use it for."21 While Luna cannot change the invasive way that American Indians have been photographed, he can take this technology and use it for his own purposes-namely, to reference these photographic histories, the stereotypes that they reveal, and to question the way stereotypic attitudes toward and expectation of Native peoples circulate in the present.

Michelle $\mathrm{H}$. Raheja has coined the term visual sovereignty to describe the tactics Native Americans have used "to confront the spectator with the often absurd assumptions that circulate around visual representations of Native Americans, while also flagging their involvement and, to some degree, complicity in these often disempowering structures of . . . dominance and stereotype." 22 In Raheja's study of representations of Native Americans in cinema, she considers both Native participants in early films produced by non-Natives, as well as contemporary Native filmmakers, noting that stereotypic images of Native Americans have become a part of Native history, especially since Native Americans at times participated in the creation of such stereotypes. ${ }^{23}$ Rather than reject such imagery, contemporary filmmakers and performance artists grapple with the implications of collusion.

Of course, there are shades of gray within the spectrum of sovereignty. Lippard references the case of Lillie Benally, a Navajo woman who allowed Laura Gilpin to photograph her in 1932, but did not consent to the publication of the image. Upon hearing that the Amon Carter Museum in Fort Worth, TX was using the photograph in museum publicity materials in 1984, she sued. ${ }^{24}$ Benally's case points to the complex web of legal and cultural issues surrounding photographs of Native Americans. Her simultaneous control and loss of control over her image-she posed for the photograph but did not consent to its publication-can be productively compared to Luna's performance. His "take a photo, leave a photo" policy permits audience members to go home with a souvenir photograph of themselves with Luna, while also ensuring that Luna comes away with a copy of the same image. There is a sense of reciprocity, in that both parties are given a copy of the photograph, and both are present in the image. But this reciprocity broke down in the 2010 performance due to the busy public area in which the work was staged. What Luna gained in terms of the symbolism of the site, he lost in terms of control over the dissemination of his work.

\footnotetext{
${ }^{20}$ Gerald V izenor, Manifest Manners : Narratives on Postindian Survivance (Lincoln: U niversity of Nebraska Press, 1999), vii.

${ }^{21}$ Mary Louise Pratt, Imperial Eyes : Travel Writing and Transculturation (London: Routledge, 1992 ), 6. Pratt approaches "contact zones" in terms of their relevance to language and literature, but the term has been more recently put to use in postcolonial theory and native studies.

22 Michelle H. Raheja, "Reading Nanook's Smile: V isual Sovereignty, Indigenous Revisions of Ethnography, and "A tanarjuat (The Fast Runner)" American Quarterly 59, no. 4 (December 2007): 1160.

${ }^{23}$ I bid., 1162.

${ }^{24}$ Lippard, Partial Recall, 31 . Benally's case is also briefly discussed in John Henry Merryman and A Ibert Edward Elsen, Law, Ethics, and the Visual Arts (New York: Kluwer Law International, 2002), 552-53. The federal district court dismissed the case because it lacked personal jurisdiction, and while an appellate court reversed the dis missal, it did not rule on the merits of the case.
} 
Photographs and film stills that document Luna's performance at the Columbus Monument show the artist, cutouts, and participants, with the addition of the photographers and gathered crowd (fig. 5). Documenting the audience and outdoor location is crucial to the 2010 iteration of Take a Picture; Luna reveals the continued perception that a real Indian can be discovered amongst the three characters he proffers. When Luna attired himself in khakis and a polo shirt he disrupted broad cultural expectations, becoming a member of the group Philip J. Deloria has termed "Indians in unexpected places." 25 By choosing instead to take a picture with Luna in his war dance regalia, participants upheld the problematic notion that Native Americans can only be seen one way, as romantic figures of peoples' past. Luna ensured that their choice designated this character the most "real" of the three Indian identities proffered, indicating that he must thus pose in this manner to gain himself a position in the realm of contemporary Western conceptions of the real. Luna does not aim to confirm or deny the realness of any depiction of Indian identity; he rather exposes the very concept of the real Indian as a construct with a complex visual history.

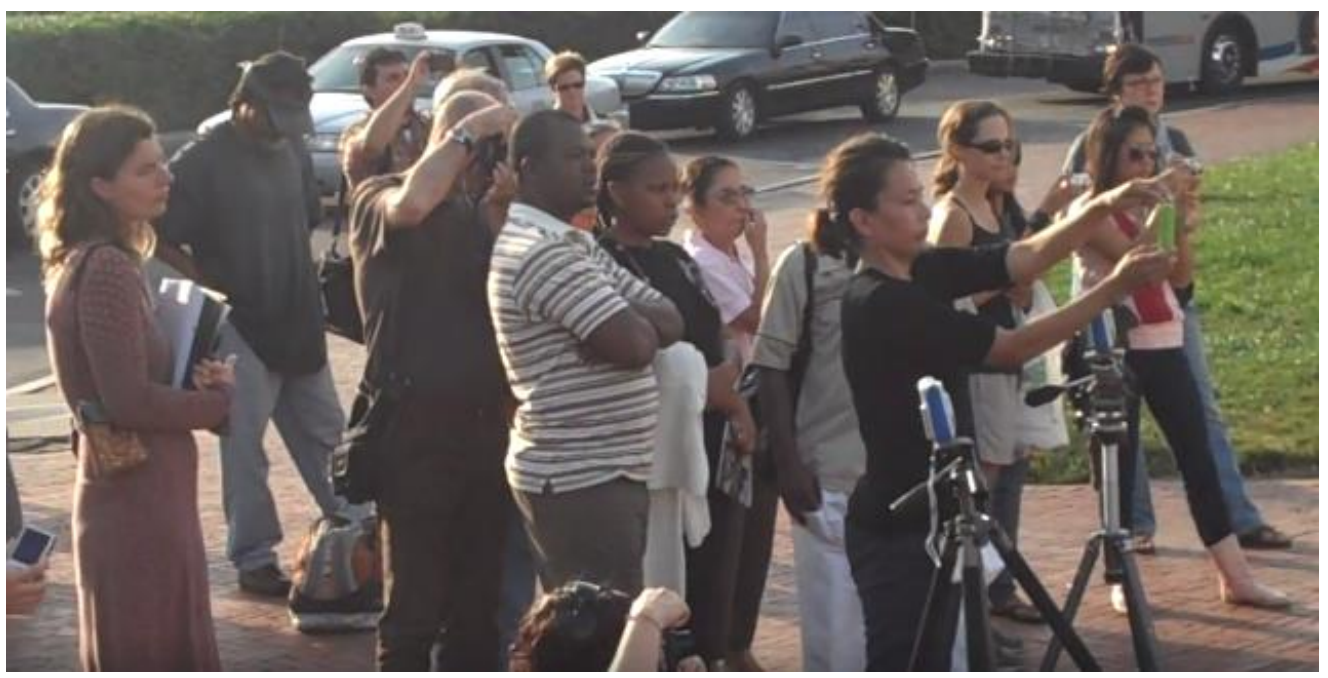

Figure 5

A udience documenting James Luna's Take a Picture with a Real Indian performed in 2010 , Was hington D.C. Film still from $\mathrm{N}$ ational Museum of the A merican Indian performance recording, accessed from http://www.facebook.com/video/video.php?v=10100243886416480

\section{Edward S. Curtis and the Legacy of the Pose}

Take a Picture draws on a long tradition of Native Americans being staged and staging themselves to fit Western audiences' expectations. Such preconceptions were both represented and produced by Edward S. Curtis's early-twentieth-century photographs of Native Americans. Luna has long been aware of Curtis and his methods: "Curtis's images were first highlighted for me in the late 1960's . . They represent that image of the Indian that people feel comfortable with and then, later on, I came to learn that some were posed,

${ }^{25}$ Philip J. Deloria, Indians in Unexpected Places (Lawrence, KS: U niversity Press of Kansas, 2004 ), 4. 
with the same regalia on two different guys, for example." ${ }^{26}$ His comments on Curtis's photographs and the conditions of their production necessitate a closer look at the se iconic yet problematic images.

Curtis's photographs have come to define Indian imagery to the extent that even now, as Luna's piece has documented, most viewers only see a real Indian before them if $\mathrm{s} / \mathrm{he}$ dresses in recognizably Native clothing. In anthropological terms, this attitude reflects the outdated idea of an ethnographic present, the artificial construction of a pre-contact people and the expectation that their modern descendants look and behave within the confines of the construction. ${ }^{27}$ Paige Raibmon notes that the fallacious notion of authenticity is judged by the degree to which Native peoples recognizably adhere to the expectation of this construction. ${ }^{28}$

Roland Barthes defines this culturally contingent recognition by way of the pose, a specific way of staging oneself, and/or the objects around oneself, to ensure that photographs conform to certain societal connotations. ${ }^{29}$ Curtis was adept at posing: he photographed Native Americans in artificially staged settings and stances, and he carefully culled his collection of markers of modernity before publishing his portfolio. Curtis a sserted at the start of his project, "above all, none of these pictures would admit anything which betokened civilization, whether in an article or dress or landscape or objects on the ground." 30

Like many of his contemporaries, Curtis viewed Native Americans as a "vanishing race," and he set out to document as many Native peoples as he could before their presumed extinction. In his published portraits of Native Americans, the sitters somberly stare out from the photos, with raking light thrown across their faces that gives all but the youngest sitters an aged appearance, as can be seen in Strike on his Head, Crow Indian, Montana (fig. 6). The figures in his photographs sit upright, giving their statures a kind of ethnographic, pseudo-scientific verity. ${ }^{31}$ Many of these portraits were, however, highly posed. Faris has described Curtis's "legacy of posing," noting that in his images of Navajos, the photos were "completely set up, using not only 'phony' costumes, additions, and poses .

\footnotetext{
26 James Luna, "James Luna," in Staging the Indian: The Politics of Representation, eds. Jill D. Sweet and I an Berry (Saratoga Springs, NY: The Tang Teaching Museum and A rt Gallery, Skidmore College, 2002), 73.

27 See Johannes Fabian, Timeand the Other: How Anthropology Makes Its Object (New York: Columbia University P ress, 1983).

28 Paige Raibmon, Authentic Indians : Episodes of Encounter from the Late-Nineteenth-Century Northwest Coast (Durham: Duke University Press, 2005).

${ }^{29} \mathrm{He}$ observes that when the pose is used, "the photograph clearly only signifies because of the existence of a store of stereotyped attitudes which form ready-made elements of signification." Barthes further notes that in the posing of objects, "the meaning comes from the objects photographed (either because these objects have... been artificially arranged in front of the camera or because the person responsible for lay-out chooses a photograph of this or that object)."Roland Barthes, "The Photographic Message," in Image - Music - Text, trans. Stephen Heath (London: Fontana Press, 1977), 22. In his analysis of posing, stereotypes, and the use of photography in identity formation, Barthes considers the photographic genre as a whole, not just images of Native peoples.

30 Edward S. Curtis, quoted in Hans Christian A dam, "Edward S. Curtis and the North A merican Indians," introduction to The North American Indian: The Complete Portfolios (New York: Taschen, 2001 ), 26.

${ }^{31}$ For analys is of these $O$ thering strategies, see Christopher M. Lyman, The Vanishing Race and Other Illusions: Photographs of Indians by Edward S. Curtis (Washington, D.C.: Smithsonian Institution Press, $1982), 61$
} 
. . but, indeed, in some cases, actual phony Navajo." 32 Not only did Curtis insist on removing any signifier of assimilated Western customs, he also emphasized their native-ness through the use of objects and activities that ancestral Navajos would have found as foreign as their descendants did, but that served as markers of real Indians for Western audiences. Catherine C. Robbins observes that "he posed Indians in the fashion of his time in sometimes fanciful contexts; his Hopi women ground corn in ceremonial dress." 33 In the photo to which she refers, four women kneel in the time-honored task of grinding meal, but instead of donning their typical day-to-day clothing, the women have adorned themselves in the jewelry, blouses, and side-buns usually reserved for ceremonial occasions (fig. 7). Whether they are doing so of their own accord or at Curtis's instruction, the activity is clearly staged: all four women are in the exact same position, as though the backbreaking work of producing cornmeal would be synchronized. A bowl of already ground meal has been placed in the center of the foreground, to further define the activity for uninitiated viewers. Nothing in the photograph is materially or temporally inaccurate, but the image collapses different facets of Hopi culture into one visually readable and formally pleasurable pose.

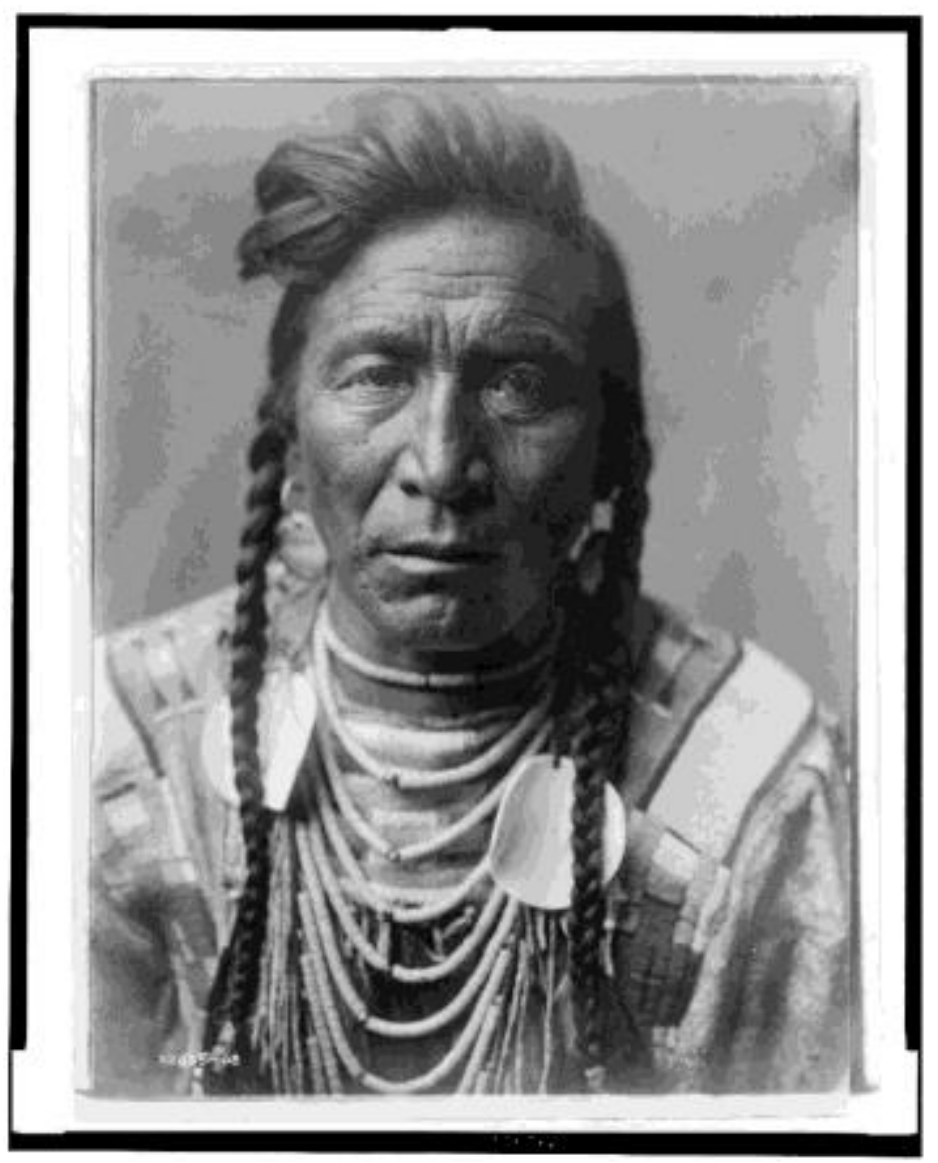

Figure 6

Edward S. Curtis, Strike on his Head, Crow Indian, Montana, ca.1908. Digital file from original. Library of Congress, Prints \& Photographs Division, Edward S. Curtis Collection, [LC-USZ62-106763].

\footnotetext{
32 Faris, Navajo and Photography, 107-108.

${ }^{33}$ Catherine C. Robbins, All Indians Do Not Live In Teepees (Or Casinos) (Lincoln: U niversity of Nebraska Press, 2011), 244-245.
} 


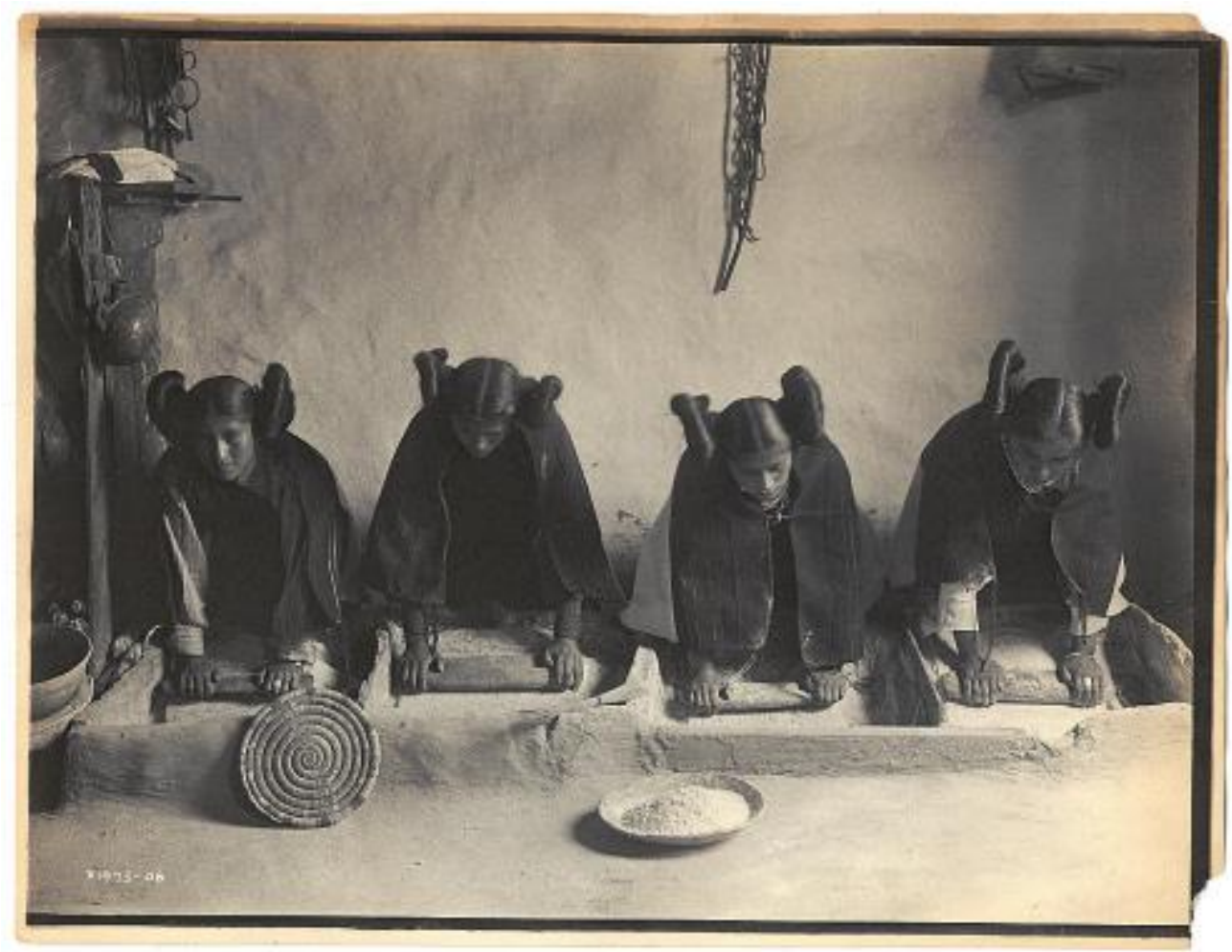

Figure 7

Edward S. Curtis, The mealing trough - Hopi, ca. 1906. Digital file from original. Library of Congress, Prints \& P hotographs Division, Edward S. Curtis Collection, [LC-DIG-ppmsca-05085].

Recent scholarship on Curtis seeks to move beyond the critique of his posing and staging activities because, as Aaron Glass notes, "it has tended to grant Curtis sole authorship and control, completely ignoring the active participation and possibly strate gic agency of the indigenous people who chose to sit and post and dress up for him." ${ }^{4}$ Glass instead examines the motivations of Kwakwaka'wakw sitters pictured in Volume Ten of Curtis's extensive book series The North American Indian. He focuses on George Hunt, a

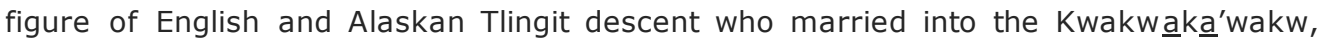
concluding that Hunt's own ethnographic interests as well as his desire to fit into his wife's culture likely influenced his decision to pose for Curtis. In a similar singular study of a sitter, Shamoon Zamir analyzes Curtis's portrait of Alexander B. Upshaw, a Crow man who studied at the Carlisle Indian School, married a white woman, and became a respected advocate for tribal rights (fig. 8). In earlier portraits, Upshaw is depicted in a suit and tie, hair neatly

\footnotetext{
${ }^{34}$ A aron Glass, "A C annibal in the A rchive: Performance, Materiality, and (In)V isibility in Unpublished Edward Curtis Photographs of the Kwakwaka'wakw Hamat'sa" Visual Anthropology Review 25, no. 2 (Fall 2009): 130 .
} 
parted. But in Curtis's photo, Upshaw sports a feathered Crow headdress as well as an elaborate Crow necklace over his bare chest.

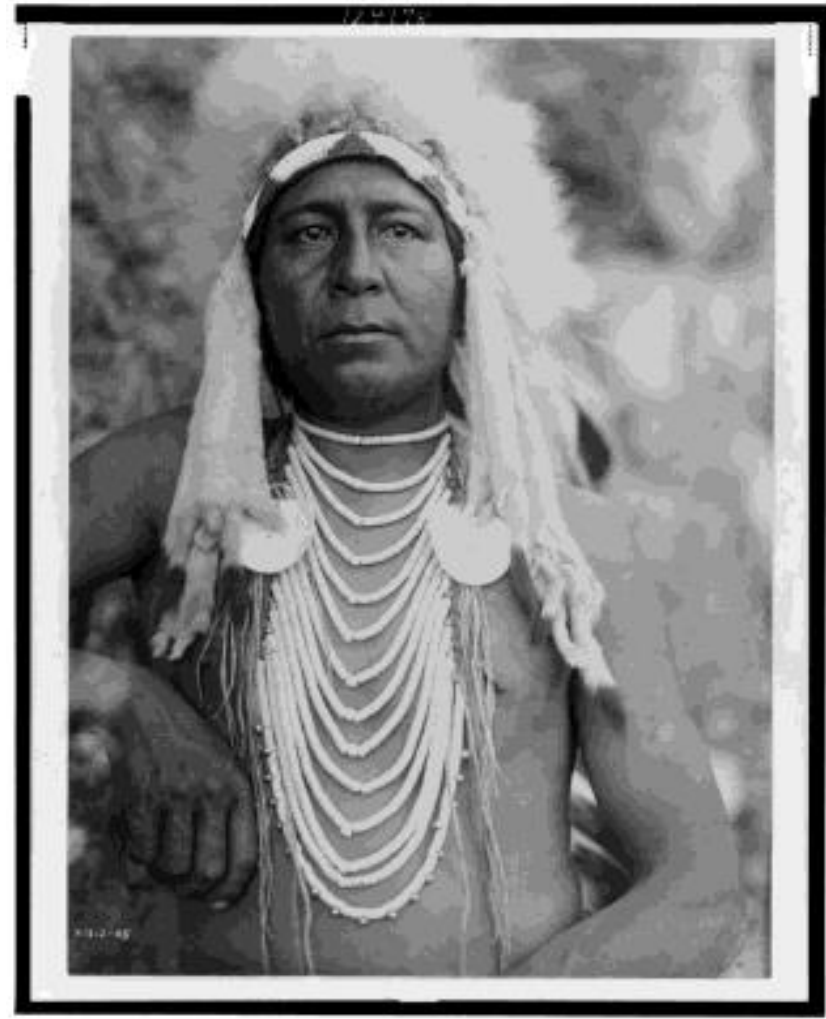

Figure 8

Edward S. Curtis, Ups haw - Aps aroke. ca. 1905 . B\&W film copy negative. Library of Congress, P rints \& Photographs Division, Edward S. Curtis Collection, [LC-USZ62-124178].

If Luna's Take a Picture voids the validity of the designation real Indian, so too does Upshaw's attire. Noting the precipitous drop in the Crow population and the cultural practices that had atrophied or been outright banned by the American government, Zamir argues that for Upshaw, "the donning of costumes and the rehearsal of tribal beliefs and practices . . . constituted a use of tradition to legitimize a contemporaneous project of social, economic, and political survival." ${ }^{35}$ He further observes that for figures like Upshaw, "the border between 'invented' and 'lived' tradition was no doubt a fluid one, if it was experienced as real at all." ${ }^{\prime 36}$ Curtis may have posed his sitters, but they also participated in active self-fashioning that affirmed Native tradition as a part of-rather than a negation of-Native modernity. The descendants of these sitters are often thankful to have these images. Gros Ventre curator George P. Horse Capture, whose grandfather was photographed by Curtis, declared: "Real Indians are extremely grateful to see what their ancestors look like or what they did and we know they are no stereotypes. No one staged the people. And we see them at their classic finest." ${ }^{13}$

\footnotetext{
${ }^{35}$ Shamoon Zamir, "Native A gency and the Making of The North American Indian: A lexander B. Upshaw and Edward S. Curtis" American Indian Quarterly 31, no. 4 (Fall 2007), 637.

${ }^{36}$ Ibid., 637.

${ }^{37}$ George P. Horse Capture, Foreword to Native Nations : First Americans as Seen by Edward S. Curtis, ed. Christopher Cardozo (Boston: Little, Brown and Company, 1993), 17.
} 


\section{The Archival Logic of the Museum}

Ethnographers also photographed Luna's ancestors. In the interest of illustrating her article on Luiseño Indians, Constance Goddard DuBois took a photo of Luna's greatgrandmother Maria Soledad Apish Trujillo and her young daughter (fig. 9). ${ }^{38}$ Unlike Curtis, who had artistic as well as ethnographic intentions, DuBois allowed elements of Western influence to enter the image just as they had the lives of the people she was documenting. Trujillo and her daughter are thus pictured in the cotton dresses that had become typical day-to-day wear for many Native American women by the turn of the twentieth century. Nonetheless, Trujillo's posture is rigid and her expression somber, conveying the same kind of ethnographic verity that Curtis sought in his portraits. Whether or not Trujillo was instructed by DuBois on the proper position to assume, her young daughter's inquisitive look and the half-hidden presence of a young boy curiously looking on from the shadows add a familial, human element to an otherwise ethnographically distancing pose.

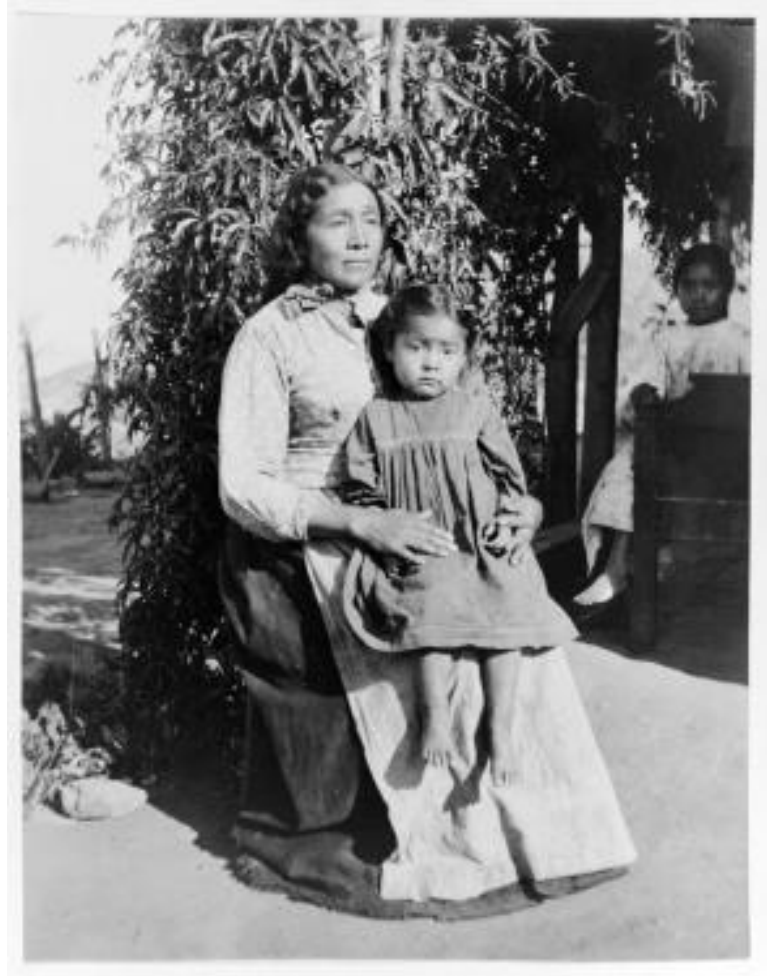

\section{Figure 9}

Constance Goddard DuBois, Trujillo's Wife \& Children, Potrero (Valley Center, San Diego County, California) 1906. Contact print on photographic paper, $5 \times 4$ in. Constance Goddard DuBois Collection, San Diego Museum of Man. Copyright 2016 San Diego Museum of Man.

To see this photograph, Luna must visit the San Diego Museum of Man where it has been categorized, catalogued, and duly archived. Jane Blocker has effectively discussed Luna's oeuvre in archival terms. She concentrates her analysis on The Artifact Piece (1987), a work first staged at the same institution housing the photograph of Luna's great

\footnotetext{
${ }^{38}$ Constance Goddard DuBois, "The Religion of the Luiseño Indians of Southern California" University of California Publications in American Archaeology and Ethnology 8, no. 3 (Berkeley: The University Press, 1908).
} 
grandmother, linking ethnographic interest in his ancestors to the continued Western epistemological obsession with archiving the Other (fig. 10). ${ }^{39}$ In the work, Luna, slightly sedated, lay wearing a breechcloth in a sand-covered museum display case, his body framed by museum labels that rhetorically ruptured romantic preconceptions of the Indian. For example, one described an unsuccessful marriage, stating: "Skin callous on ring finger remains, along with assorted painful and happy memories." The description of a physical callous and the memories it evokes for the artist brought Luna's Native body into the present and his life into the contemporary context, as did one of the vitrines placed near his body (fig. 11). Contained within was a personal potpourri of mementos from the artist's own history, including a driver's license, diploma, divorce papers, tapes and records of contemporary musicians, political buttons, comic books, and small figurines. ${ }^{40}$ By providing information about Luna's own life, the placards and the vitrine spoke to what Serge Gruzinski has called the mestizo mind and Blocker terms a history of mélange; that is, a society that exhibits ambiguously ambivalent signs of a composite cultural identity. ${ }^{41}$ Such signs are generally repressed in the institutional context to what Jean Fisher calls "the necrophilous codes of the museum." ${ }^{42}$ Museums' visual and rhetorical cues often represent indigenous peoples as anachronistic to modern life, perpetually vanishing because they are characterized as already of the past. As Blocker notes, the Western institutional archive favors bones over flesh, the ancients over their living descendants. ${ }^{43}$

Luna's intervention was thus to rupture this archival assumption of pastness by bringing his own bodily presence into the museum, emphasizing the present by parodying the institutional insistence on the past. ${ }^{44}$ Performance proves a particularly apt strategy for disrupting the Western fantasy of the "vanishing race," for, as Peggy Phelan notes, absence always underlies the presence of performance. ${ }^{45} \mathrm{Her}$ point is particularly poignant for Native performers who stage the constructed aspect of Native identity, as their a udiences often paradoxically view them as part of a vanished culture, despite the performers' physical presence. If Take a Picture insists on the presence of a khakis-clad contemporary Native American even while highlighting the way in which most audience members designate the regalia that of the real Indian, The Artifact Piece stresses the lived presence and physical

\footnotetext{
39 Jane Blocker, "A mbivalent Entertainments: James Luna, Performance, and the A rchive," Grey Room 37 (Fall 2009): 55-62.

${ }^{40}$ For a more complete list, see Jennifer A. Gonzalez, Subject to Display: Reframing Race in Contemporary Installation Art (C ambridge, MA: The MIT Press, 2008), 40.

${ }^{41}$ Serge Gruzinski, The Mestizo Mind: The Intellectual Dynamics of Colonization and Globalization, trans. Deke Dusinberre (New York: Routledge, 2002), 9; Blocker, 61. These terms are part icularly pertinent in discussing Luna's work, as he identifies as both Luiseño and Mexican-American has addressed his multiple racial identities in other works.

42 Jean Fisher, "Jimmie Durham," in Matoaka Ale Attakulakula Anel Guledisgo Hnihi, exhibition catalogue (London: Matt's Gallery, 1988), 12.

43 Blocker borrows her use of the "flesh over bone" archival logic from Rebecca Schneider, who asserts that, "in the archive, flesh is given to be that which slips away. Flesh can house no memory of bone. O nly bone speaks memory of flesh." Blocker, 54; Rebecca Schneider, "A rchives: Performance Remains" Performance Research 6, no. 2 (Summer 2001): 102.

${ }^{44}$ He does so by way of the pose and, though I do not discuss them here, mimicry and masquerade - and the discourses surrounding such strategies-are also important aspects of his work. A rtis ts with feminist agendas have long used these strategies; indeed, Luna learned them from Eleanor Antin, a feminist artist and instructor at the University of California, I rvine while he was a student there.

45 Peggy Phelan, Unmarked: The Politics of Performance (New York: Routledge, 1993), 146-166.
} 
present-ness of a contemporary Native American through the stereotypical staging methods of the museum, which are usually used to stress the historical past-ness of the cultures on display. Luna asserts Native agency by parodying the typical lack thereof in the institutional context.
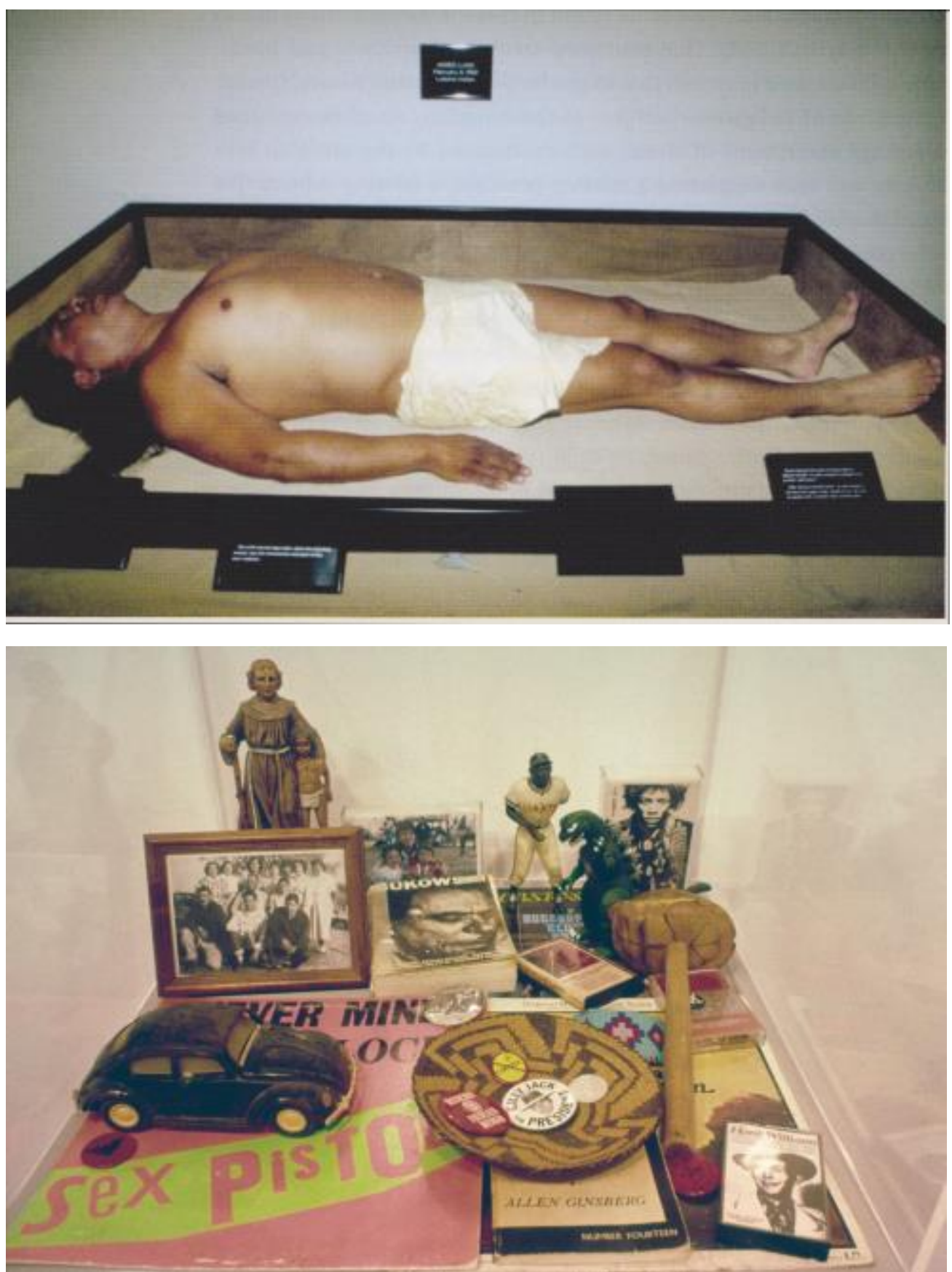

Figure 10

James Luna, The Artifact Piece, installation view, 1987. Live performance-installation, San Diego Museum of Man. Photographer unknown. Copyright 2016 San Diego Museum of Man.

\section{Figure 11}

James Luna, The Artifact Piece, installation view (vitrine), 1987. Live performance-installation, San Diego Museum of Man. Photographer unknown. Copyright 2016 San Diego Museum of Man. 


\section{Luna's Contemporaries}

Luna's work is often compared to Coco Fusco and Guillermo Gómez-Peña's Two Undiscovered Amer-Indians Visit the West (1992-1994), another performance piece that plays off stereotypes of essentialized Native identity in order to reveal them as such. In the work, the artists presented themselves as Amer-Indians from an island in the Gulf of Mexico that had somehow escaped Western discovery (fig. 12). In various public spaces such as museums, public squares, universities around the world, they had themselves presented in a cage containing assorted material markers of their fictional everyday lives. So-called experts were on hand to answer questions about them. Like the vitrine of contemporary objects included in Luna's The Artifact Piece, Fusco and Gómez-Peña's performative project included a number of props that applied pressure on the notion of indigenous a uthenticity; to urist badges, plastic sunglasses, a laptop, a bottle of Coca-Cola and more made up what Caroline Vercoe calls "their living cargo-culture diorama." 46 Fusco recalls that upon seeing this assortment, "a Native American elder from the Pueblo tribe of Arizona . . . said that our performance was the most real thing about the Native Americans displayed in the whole museum. He said the installation and performance ought to be permanent to give people a very clear idea of the Native American experience. ${ }^{\prime 47}$ However, other viewers questioned the legitimacy of Natives possessing commercial items. The artists were surprised by the negative reactions. While they assumed their commentary would be clear as a construct, many people engaged with the performance believing that the artists actually were Natives from Guatinaui, their fictional homeland.

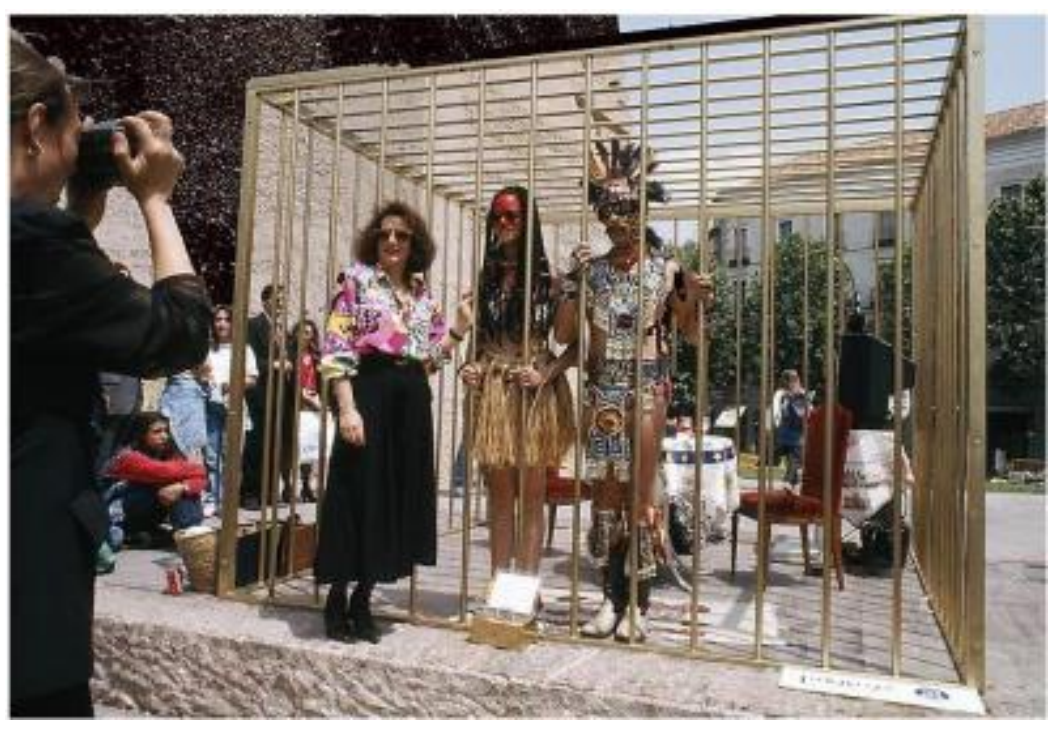

Figure 12

Coco Fusco and Guillermo GómezPeña, Two Undiscovered Amer-Indians Visit the West, 19921994. Live performanceinstallation, Columbus Plaza, Madrid, Spain. Copyright Coco Fusco.

\footnotetext{
${ }^{46}$ Caroline Vercoe, "A gency and A mbivalence: A Reading of Works by Coco Fusco," in The Bodies that Were Not Ours, and Other Writings, ed. Coco Fusco (New York: Routledge, 2001), 233.

${ }^{47}$ Coco Fusco, qtd. in A nna Johnson, "Coco Fusco and Guillermo Gómez-Peña" Bomb 42 (Winter 1993), accessed May 4, 2012, http://bombsite.com/issues/42/articles/1599.
} 
Part of the performance involved the sale of Polaroid images to audience members who posed with the so-called savages for souvenir pictures, a strategy that links the project to Luna's Take a Picture-which he had performed just one year before Fusco and Gómez-Peña first staged Two Undiscovered Ameri-Indians-and points to a Western history of using the Othered body for entertainment. Luna's contemporary Zig Jackson (Mandan, Hidatsa, Arikara) also bitingly commented on the continued tourist tendency to photograph traditional Native American culture in his Indian Photographing Tourist Photographing Indian series from 1991 (fig. 13). ${ }^{48}$ The tourists, clad in cargo shorts, blue jeans, and anoraks, view the ceremonial dance through their expensive cameras, clicking away, seemingly oblivious to their own intrusion and Jackson's doubled documentation. Formally, the layering of lens views in his images echoes those of images taken by bystanders of Luna's Take a Picture as well as Navajo Children; in each instance the resulting imagery shows Native bodies being photographed. The identities of the photographers documenting the Native peoples, and the photographers documenting the documenters shift from photo to photo, but the Native body as Other is central to all three images both pictorially and rhetorically.

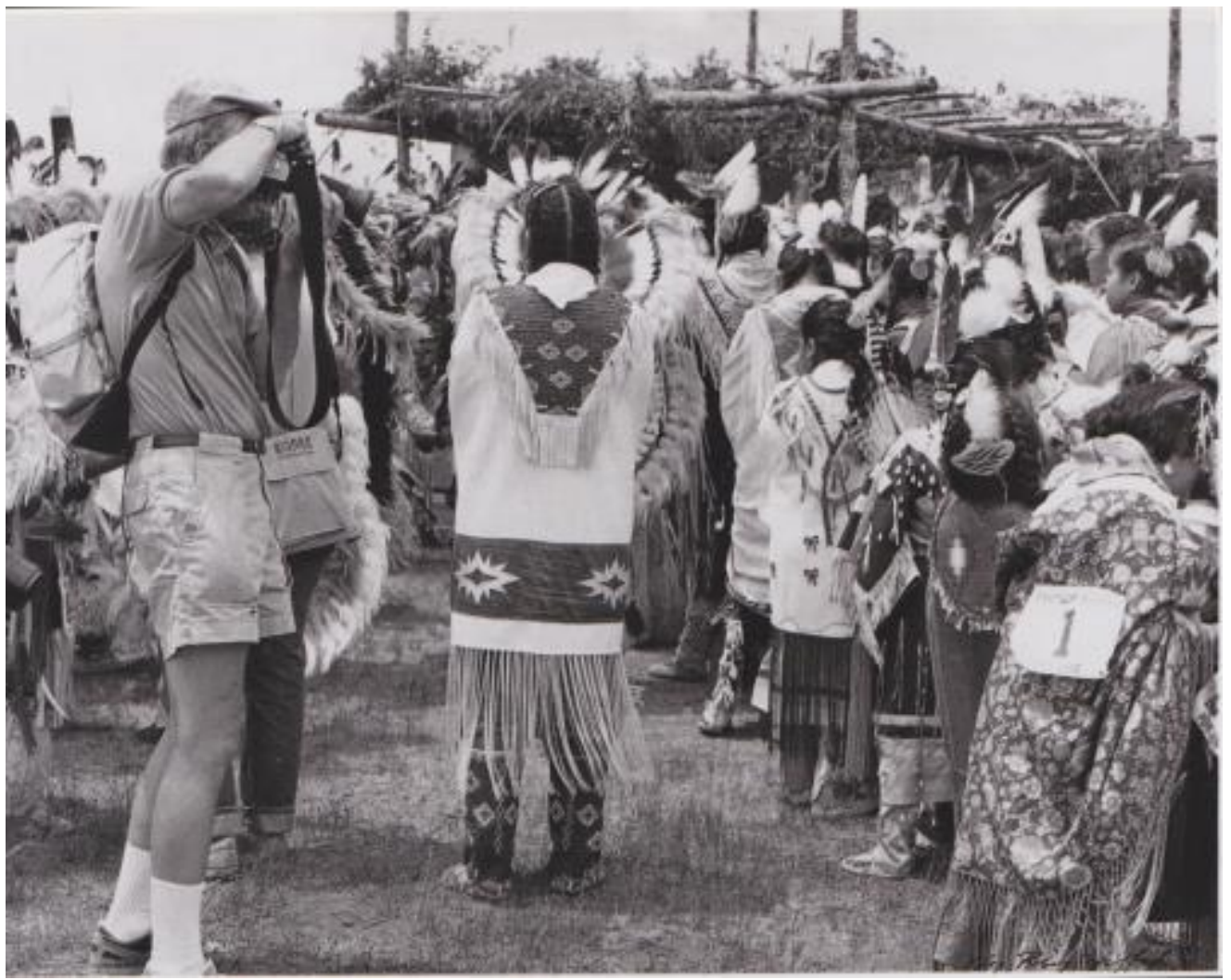

Figure 13

Zig Jackson, Untitled from Indian Photographing Tourist Photographing Indian series, 1991. Silver gelatin print, $16 \times 20 \mathrm{in.} \mathrm{Image} \mathrm{courtesy} \mathrm{of} \mathrm{Zig} \mathrm{Jackson.}$

\footnotetext{
${ }^{48}$ For more on this project, see "Social I dentity: A V iew from Within, P hotographs by Zig Jackson," in Strong Hearts: Native American Visions, ed. Peggy Roalf (N ew Y ork: A perture, 1995), 34 -37.
} 


\section{Conclusion}

James Luna's oeuvre accommodates the historiographical shift in discourse on images of Native Americans from the exploited Native body towards the more complex account of indigenous agency. Examining the work-and the evolving reception thereof-of Native American artists like Luna allows for a nuanced analysis of this shift, and illuminates the role that indigenous cultural producers have played in steering the dialogue towards an acknowledgement of Native agency. Explaining the impetus behind Take a Picture, Luna stated, "I saw some Indian selling his red ass to sell jewelry, and I was ashamed but I knew what he was doing - he was working. I've worked too . . . as Indians we have all been on the tourist line. ${ }^{\prime 49}$ His sentiment echoes that of Paul Chaat Smith, who describes the experience of being a Native American as partially "our own frequent willingness to lead the searchers in their quest for the real Indian." 50 Viewed sequentially, the various iterations of Take a Picture thus bring to light dual visual historical narratives: the stereotypical depictions of Native Americans by non-Natives, and the way Native Americans have posed themselves to fit and challenge these Western stereotypes.

The history of Native self-staging to fit Western expectations productively problematizes a shortsighted reading of Luna's work. Louis Kaplan argues that, "if we take a picture of another person or of a group, we pose them in a relationship with exteriority-exposing them to the look of others and even to themselves as other." 51 The complex relationships between identity, agency, and the Other-particularly as enacted in the pose and the photograph-are fraught for Native Americans whose past continues to be colonized by Western representational epistemologies that encroach on their lived present. Yet, as Catherine Robbins notes, echoing George Horse Capture's appreciation for Curtis's photographs, "some of Curtis's 'vanishing' Indians-alive and well today-admire his portraits." 52 Posed though they may be, photographs like Curtis's are a part of Native A merican history and can be admired for their visual pleasure, even with an awareness of their construction. ${ }^{53}$ Extrapolating from an earlier version of Take a Picture, Blocker asserts that, "even as the ethnographer, curator, and historian take a picture, they also leave a picture." 54 In her estimation, this "trade," while potentially exploitative, allows for continued Native presence in the face of "a visual discourse working hard to make them disappear. "55 C haracterizing such interactions as a "trade" acknowledges the agency of Native Americans who may have strategically posed for documentary photographs. Indeed, even while Curtis characterized his sitters as the "vanishing race," those sitters insisted on their continued existence, their survivance, by agreeing to pose for him. Regardless of the participants' selection of real

\footnotetext{
${ }^{49}$ Luna, quoted in Blocker, "Failures of Self-Seeing: James Luna Remembers Dino," PAJ: A Journal of Performance and Art 23, no. 1 (January 2001), 31.

${ }^{50}$ Smith, "Ghost in the Machine," 9.

51 Louis Kaplan, "Being Exposed: Thinking Photography and Community in Spencer Tunick's Naked World Through the Lens of Jean-Luc Nancy," in Photography: Theoretical Snapshots, eds.J.J Long, Andrea Noble, and Edward Welch (New York: Routledge, 2009), 128.

52 Robbins, All Indians, 245.

53 In a way, such posing was inevitable; Lippard notes that "the pose is an imposition, since Native people had not traditional way of sitting for a portrait or a photograph; self-representation in that sense was not part of the cultures." Lippard, Partial Recall, 39.

54 Blocker, "A mbivalent Entertainments," 73.

55 Ibid.
} 
Indian to be photographed with in Take a Picture, Luna's very presence reminds his audience that Native peoples have not disappeared.

While the photograph and the pose are key to Luna's Take a Picture, the multiple performances of the work also necessitate a consideration of different forms of reenactment. Colloquially speaking, to reenact is simply to act or perform a gain. In this sense, Luna can be seen to reenact two aspects of reenactment: First, since most audience members elect to have their photograph taken with Luna in a headdress, the performance can be interpreted as a reenactment of stereotypical Western conceptions of the real Indian. Second, Luna's purposeful participation in this performance indicates that it is a reenactment of the way Native Americans have frequently re-appropriated Western stereotypes for various reasons.

But these forms of reenactment could be carried out with a single performance; the multiple restaging points to a third and fourth aspect of reenactment pertinent to Luna's work: Thirdly, Luna insists on the enduring presence of the so-called vanishing race by continuing to reenact Take a Picture, for while absence may underlie the presence of performance, performances that are staged again and again disrupt disappearance. Finally, because no performance can ever be repeated exactly, and no performance can ever replicate past attitudes exactly, reenactments have an emancipatory potential. In his Debordian essay "An Arena in which to Reenact," Sven Lütticken notes: "Operating within contemporary performative spectacle, if from a marginal position, art can stage small but significant acts of difference. From this perspective, historical reenactment and living history too may constitute a potential waiting to be activated." 56 In this sense, Take a Picture does not just re-inscribe stereotypical attitudes through reenactment. Rather, the restag ing of the performance allows for intervention, for potentially changing these attitudes. Luna's staging strategy for Take a Picture thus far seems to encourage viewers to choose the character in regalia as the real Indian, thereby pointing to the continued circulation of Native American stereotypes. Yet the work also provides for potentially different reactions: despite pushing viewers to choose his regalia-attired Indian, Luna seems to paradoxically hold a simultaneous expectation with each restaging that this time, the outcome will be different. While stereotypic imagery will always be a part of Native American history, future attitudes regarding Native Americans may change. Perhaps in performances of Take a Picture with a Real Indian yet to come, audience members' choices will be more evenly distributed amongst the three constructions of Indian identity; since the very designation "real Indian" is a fallacy, none of these constructions represent the real Indian, and yet, in a way, they all do.

\footnotetext{
56 Sven Lütticken, "An A rena in Which to Reenact," in Life, Once More: Forms of Reenactment in Contemporary Art (Rotterdam: Witte de With, Center for Contemporary Art, 2005), 60.
} 
$(\mathrm{cc})$ BY

New articles in this journal are licensed under a Creative Commons Attribution 4.0 United States License.

\section{ULLS D-Sent}

This journal is operated by the $U$ niversity Library System of the $U$ niversity of Pittsburgh as part of its D-Scribe Digital Publishing Program, and is co-sponsored by the University of Pittsburgh Press. 